\title{
Accident vascular cerebral acut ischemic la un pacient cu forma digestivă a infecției COVID-19
}

\author{
Oana Obrișcă1', Anca A. Arbune', Mirela Drăghici', Eugenia Irene Davidescư ${ }^{2,3}$, \\ Ayghiul Mujdaba-Elmi², Adriana O. Dulamea ${ }^{1,3}$ \\ ${ }^{1}$ Clinica de Neurologie, Institutul Clinic Fundeni, București, România \\ ${ }^{2}$ Clinica de Neurologie, Spitalul Clinic Colentina, București, România \\ 3Universitatea de Medicină și Farmacie „Carol Davila“, București, România
}

\begin{abstract}
REZUMAT
Noul coronavirus SARS-CoV-2 determină cea mai importantă pandemie din ultimul secol, care continuă să evolueze și ale cărei consecinţe sunt încă incomplet elucidate. Prezentăm cazul unui bărbat în vârstă de 65 de ani, fără comorbidităţi semnificative, care s-a prezentat în serviciul de neurologie cu deficit motor la nivelul membrelor drepte, asimetrie facială, dizartrie, asociate cu vărsături și cefalee, instalate brusc. Examenul neurologic iniţial a sugerat accident vascular cerebral (AVC) acut, dar CT-ul cerebral iniţial nu a evidenţiat modificări de ischemie precoce sau hemoragice. Conform protocolului terapeutic, s-a iniţiat tromboliza intravenoasă, care a evoluat iniţial fluctuant, fiind întreruptă din cauza hematemezei intempestive, urmată de diaree, crampe abdominale si vărsături recurente. Imagistica cerebrală repetată a confirmat diagnosticul de AVC acut în teritoriul vertebrobazilar, iar examenul CT abdominal a evidenţiat modificări inflamatorii la nivelul colonului proximal și perirenal, precum și pleurezie dreaptă minimă, cu zone de hipoventilaţie la nivelul bazelor pulmonare. Analizele de laborator au indicat ușoară leucocitoză cu neutrofilie, nivel crescut al D-dimerilor și moderată retenţie azotată. În contextul epidemic COVID-19, pacientul a fost testat pentru SARS-CoV-2, care a fost confirmat pozitiv prin examen RT-PCR. Electrocardiograma iniţială a evidenţiat fibrilaţie atrială, necunoscută anterior, sugerând mecanismul cardio-embolic al AVC-ului ischemic, posibil potenţat de infecţie. Evoluţia ulterioară a pacientului a fost favorabilă, beneficiind de prevenţie secundară cu anticoagulant oral, asociat cu tratament hipotensor și statină. În concluzie, infecţia COVID-19 se poate asocia urgenţelor vasculare, chiar în absenţa simptomelor sugestive, febrile sau respiratorii. Manifestările gastrointestinale, coroborate cu imagistica abdominală, pot reprezenta indicii pentru infecţia concomitentă cu SARS-CoV-2, constituind o particularitate a cazului.
\end{abstract}

Cuvinte cheie: COVID-19, AVC ischemic, tromboliză, diaree

\author{
Abbreviations \\ ACE2 Angiotensin converting enzyme 2 \\ ALT Alanin-aminotransferază \\ AST Aspartate-aminotransferază \\ ASPECTS The Alberta Stroke Programme \\ Early CT Score \\ AVC Accident vascular cerebral
}

\author{
CK Creatinkinază \\ CK-MB Fracţia miocardică a CK \\ NIHSS The National Institutes of Health Stroke Scale \\ SOFA Sequential organ failure assessment \\ RT-PCR Reverse-transcriptase-polymerase-chain-reaction \\ VNR Valori normale de referinţă
}

\section{INTRODUCERE}

Emergenţa noului coronavirus SARS-CoV-2 a declanșat cea mai importantă pandemie din ultimul secol, care continuă să evolueze și ale cărei consecin- ţe sunt încă incomplet elucidate. Denumită infecţia COVID-19, boala coronavirală simptomatică evoluează în majoritatea cazurilor cu forme ușoare și medii, $20 \%$ cu forme severe însoţite de detresă respiratorie, 
dintre care 5\% progresează către forme critice, cu șoc septic, insuficienţă multiplă de organe și tulburări majore de coagulare, care impun îngrijiri de terapie intensivă (1).

Riscul major de deces a fost dovedit la persoanele cu vârsta peste 60 de ani sau care asociază comorbidităţi, precum hipertensiune arterială, boli coronariene, diabet zaharat, obezitate, boală pulmonară obstructivă cronică sau tabagism $(2,3)$. Factorii de predicţie identificaţi pentru riscul de deces sunt: scorul SOFA crescut, valorile D-dimerilor peste $1 \mu \mathrm{g} / \mathrm{ml}$, niveluri serice ridicate ale interleukinei 6 , troponinei-I, lactat-dehidrogenazei (LDH) și feritinei, precum și limfopenia marcată (2-4). Studiile au corelat gravitatea bolii cu numărul absolut de leucocite și neutrofile serice și cu nivelul proteinei C-reactive (5-7).

Infecţia COVID-19 are un caracter sistemic. Cele mai frecvente manifestări sunt febra, tusea, scurtarea respiraţiei, frisoanele, durerile musculare, cefaleea, disfagia, pierderea simţului gustativ sau olfactiv (13). Tulburările neurologice pot preceda tabloul clinic tipic, prin afectarea sistemului nervos central (vertij, cefalee, alterarea conștienței, accidente vasculare cerebrale, mielită transversă) sau prin afectarea sistemului nervos periferic (disgeuzie, hiposmie, polineuropatie acută de tipul Guillain-Barré, durere neuropată) $(2,8,9)$.

Simptomele digestive, cu diaree, anorexie, vărsături, dureri abdominale, se asociază la mai puţin de $10 \%$ dintre cazuri (10).

$\mathrm{Au}$ mai fost raportate forme clinice cu manifestări dermatologice, cardio-vasculare, vasculitice. Pe măsură ce studiile vor progresa în direcţia elucidării mecanismelor patogenice ale SARS-CoV-2, vom putea înţelege mai bine influenţa acestei infecţii acute asupra evoluţiei unor patologii cronice.

\section{PREZENTAREA CAZULUI}

Un bărbat în vârstă de 65 de ani, nefumător, fără comorbidităţi cunoscute, s-a prezentat în clinica de neurologie pentru scăderea forţei musculare la nivelul membrelor drepte, asimetrie facială și tulburare de vorbire, simptomatologie debutată brusc, cu 2 ore și 40 minute anterior internării. Pe parcursul transportului cu ambulanţa, pacientul a acuzat cefalee uşoară, greaţă şi vărsături. La momentul internării, pacientul era somnolent, cu tensiunea arterială 180/100 mmHg, puls neregulat $75 \mathrm{bpm}$, fără sufluri carotidiene sau cardiace, saturaţia oxigenului $97 \%$, examen clinic pulmonar și abdominal în limite normale, diureză prezentă. Examenul neurologic a evidenţiat dizartrie severă, strabism divergent al ochiului stâng, anizocorie, pareză facială centrală dreaptă, hemiplegie dreaptă, semn Babinski prezent pe dreapta, fără deficite senzitive sau ataxie, cu un scor total NIHSS de 14/42 puncte. Prima electrocardiogramă a confirmat fibrilaţia atrială. La evaluarea imagistică iniţială, scorul ASPECTS a fost de 10 puncte, nu au fost evidenţiate semne de ischemie precoce sau hemoragie la CT cerebral (figura 1).

Diagnosticul prezumtiv a fost de AVC ischemic acut în teritoriul vertebrobazilar. Conform protocolului pentru tratamentul AVC acut, verificarea criteriilor de eligibilitate a permis decizia iniţierii tratamentului de revascularizare intravenoasă cu Alteplase $(0,9 \mathrm{mg} /$ $\mathrm{kg}$ ), la aproximativ 3 ore și 30 minute de la debutul simptomatologiei (11).

Pe parcursul trombolizei, simptomatologia neurologică a fluctuat, alternând între somnolenţă profuză și hemiplegie dreaptă, respectiv ameliorare aproape completă. Administrarea Alteplase a fost întreruptă după ce s-a infuzat $75 \%$ din doza stabilită, din cauza unui episod de hematemeză, urmat de alte vărsături, diaree și dureri abdominale, care au contribuit la neliniște și agitaţie psihomotorie marcate.

Examinarea CT-ului cerebral repetat la 24 ore după tromboliză a evidenţiat o hipodensitate recentă în porţiunea superioară a emisferului cerebelos stâng, sugerând AVC ischemic recent în teritoriul arterei cerebeloase superioare (figura 1). Completarea investigaţiilor imagistice cu CT abdomino-pelvin a fost impusă de simptomatologia gastrointestinală, care a relevat infiltrate inflamatorii nespecifice la nivelul colonului proximal și perirenal stâng, fără semne de peritonită sau ascită, precum și pleurezie dreaptă în cantitate mică și arii de hipoventilaţie la nivelul bazelor pulmonare (figura 2).

Evaluarea de laborator a indicat ușoară leucocitoză, cu raportului neutrofile/limfocite în creștere, de la 10,5 la 364,6 în primele 24 de ore. Markerii de inflamaţie (fibrinogen, proteina C-reactivă), nivelurile serice ale ALT, AST, CK și CK-MB au fost normale, dar au fost găsite valori crescute ale LDH (1,2 x VNR), creatininei serice $\left(e G F R=57 \mathrm{ml} / \mathrm{min} / 1,73 \mathrm{~m}^{2}\right)$ și Ddimerilor $(9,89 \mu \mathrm{g} / \mathrm{ml})$. În contextul epidemic COVID-19, la internare s-a efectuat screening-ul acestei infecţii prin testul RT-PCR-SARS-Cov-2 din 

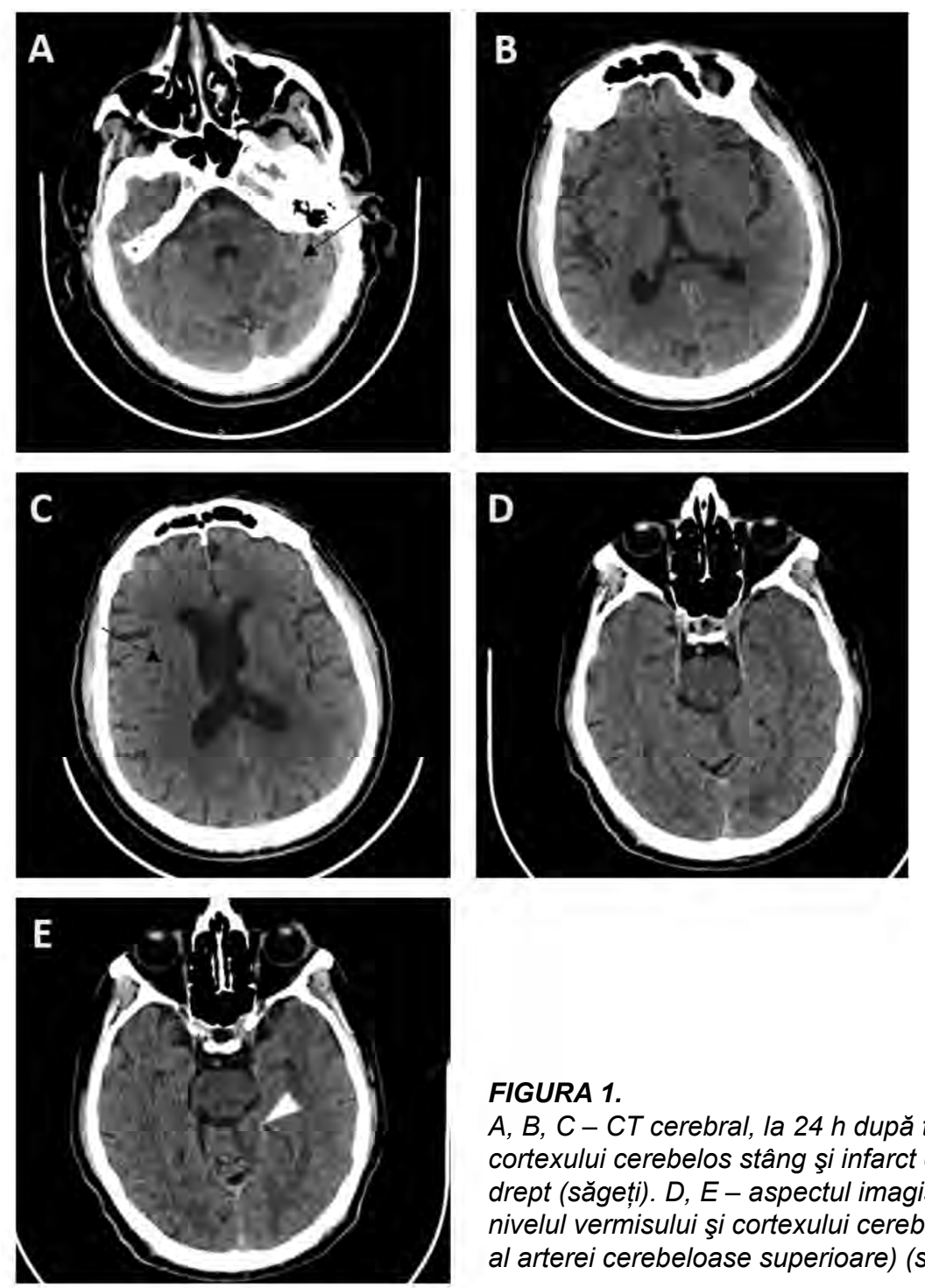

FIGURA 1.

A, B, C-CT cerebral, la 24 h după tromboliză: hipodensitate recentă la nivelul cortexului cerebelos stâng şi infarct cerebral lacunar sechelar, lenticulo-capsular drept (săgeți). D, E - aspectul imagistic la 7 zile: infarctul cerebral constituit, la nivelul vermisului şi cortexului cerebelos superior stâng (teritoriul de vascularizație al arterei cerebeloase superioare) (săgeți).

secreţiile nazo-faringiene, al cărui rezultat pozitiv a fost disponibil după începerea trombolizei, impunând reevaluarea cazului şi revizuirea anchetei epidemiologice.

Pacientul a fost transferat către un spital dedicat COVID-19, unde a beneficiat de investigaţii care au exclus afecţiuni ale vaselor cervicale mari, valvulopatii cardiace sau formaţiuni trombotice intracardiace. Simptomatologia neurologică şi digestivă s-a îmbunătăţit considerabil în următoarele zile. În ciuda prognosticului iniţial nefavorabil, pacientul s-a externat vindecat virusologic (2 teste consecutive RT-PCR-SARS-CoV-2 negative), echilibrat cardio-respirator, fară acuze digestive, recuperat semnificativ neurologic, persistând hemipareză dreaptă ușoară și dizartrie discretă (scor Rankin modificat de 2 puncte). La externare, pacientul a primit recomandare pentru prevenţia secundară cu anticoagulant oral (apixaban $5 \mathrm{mg}$ x 2/zi), asociat cu tratament antihipertensiv și statină.

\section{DISCUȚII}

Expunerea acestui caz a fost motivată de identificarea unor particularităţi (tabelul 1).

Patogenia noului coronavirus SARS-CoV-2 este explicată de afinitatea faţă de receptorii enzimei de conversie a angiotensinei 2 (ACE2), aflaţi pe suprafața unor celule de care se leagă, apoi intră în celulă și determină efect citopatic (12). Receptorii ACE2 au densitate crescută la nivelul celulelor alveolare și macrofagelor pulmonare, explicând predominanţa manifestărilor respiratorii, dar sunt prezenți și la nivelul celulelor endoteliale, distribuite sistemic, implicând leziuni vasculitice și alterarea coagulării (1). Datele experimentale au evidenţiat prezenţa receptorilor ACE2 și la nivelul altor celule, care sunt potenţiale ţinte ale virusului, de exemplu monocite, celule miocardice, celule epiteliale ale tubulilor renali distali, 


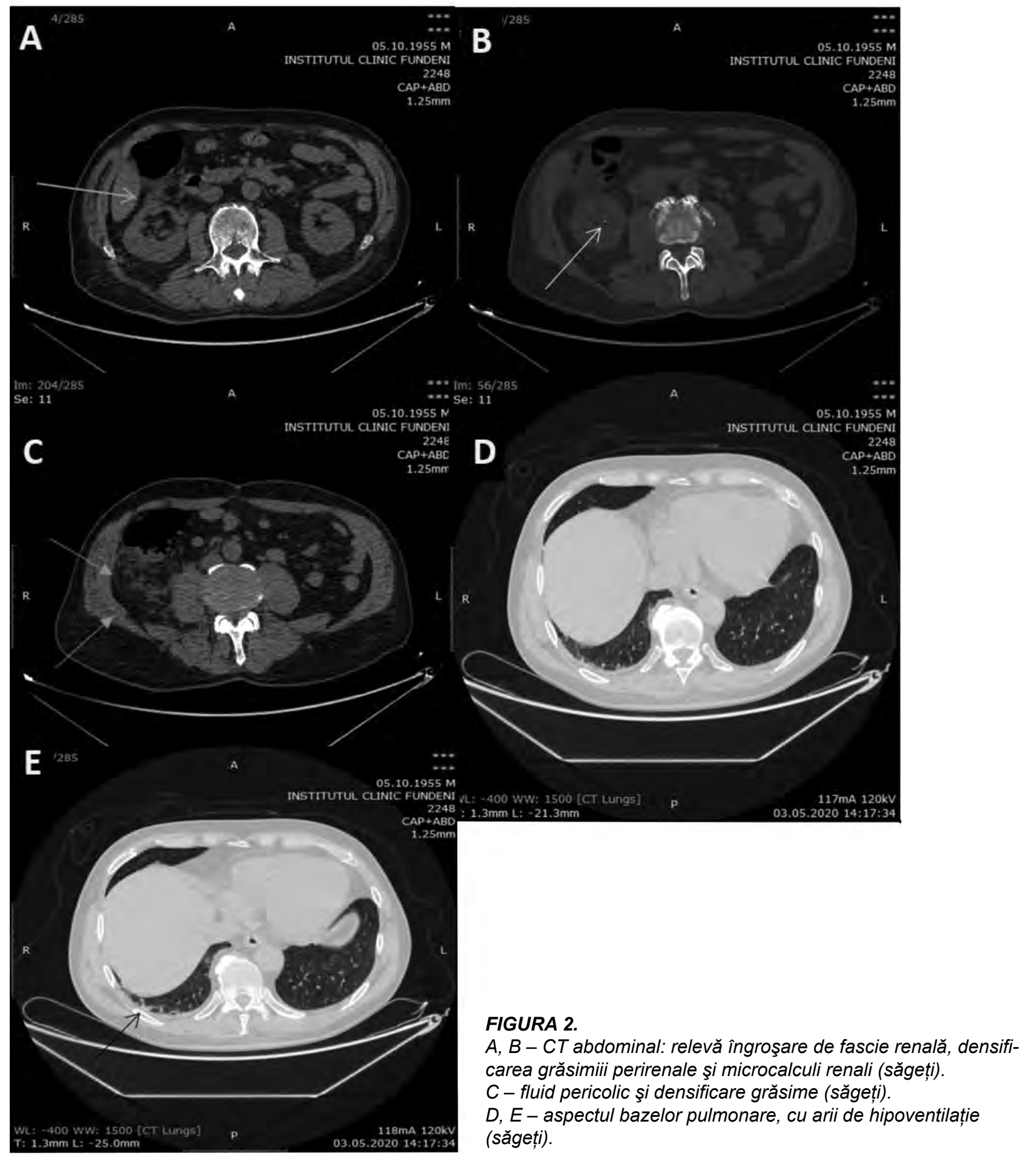

celule testiculare, hipofizare, din glandele paratiroide, cortexul suprarenalei, glandele sebacee, dar și celulele epiteliale din tractul digestiv, celulele parietale gastrice, celulele acinare pancreatice (12).

Infecţia virală determină un răspuns inflamator important, cel mai probabil datorat producţiei accelerate de citokine tip 2. Inflamaţia endoteliului vascular poate fi rezultatul indirect al hiperproducţiei de citokine, dar și efectul direct al virusului SARS-CoV-2 asupra receptorilor endoteliali de angiotensină $(2,4)$. Alterarea funcţiei limfocitelor T și B, mai ales la persoanele vârstnice, asociate cu niveluri ridicate ale factorilor procoagulanţi, determină modificări hemodinamice $(4,5)$. În consecinţă, infecţia SARS-CoV-2 determină reacţie hiperinflamatorie și afectare multiorganică (6).

Deși manifestările digestive nu sunt considerate definitorii pentru diagnosticul infecţiei COVID-19, 
TABEL 1. Particularitățile cazului cu infecție COVID-19 şi AVC

1. Infecţia COVID-19 a fost a 敬 lipsind simptomatologia caracteris ă,? cu febră, tulburări respiratorii, tulburări de gust sau de miros, atât la debut, cât și în cursul evoluţiei bolii.

2. Accidentul vascular ischemic acut a fost inaugural pentru infecţia COVID-19, la un pacient vârstnic, dar aparent fără comorbidităţi, trombolizat incomplet din cauza apariţiei unui eveniment hemoragic.

3. Hemoragia diges ă? apărută în contextul trombolizei a fost urmată de manifestări diges e? clinice și imagis compa cu forma diges ă? a infecţiei COVID-19, a 䡚 de literatura medicală sub $10 \%$ dintre cazuri.

4. Lipsa indiciilor clinice și epidemiologice a condus la internarea pacientului într-o unitate non-COVID, cu implicaţii asupra riscului profesional de infecţie a personalului expus în îngrijirilor și asupra deciziei de tromboliză.

5. Decizia trombolizei înaintea obţinerii rezultatului testului RT-PCR-CoV-2 a fost tă de necesitatea încadrării în perioada de „fereastra ter ătri și lipsa criteriilor clinice și epidemiologice pentru suspiciunea de COVID-19.

acuzele gastrointestinale sunt menţionate deseori pe parcursul bolii, atribuite leziunilor epiteliului intestinal, leziunilor vasculare abdominale sau reacţiilor secundare unor medicamente (14). Manifestări digestive raportate mai frecvent sunt diareea, greaţa sau vărsăturile și durerea abdominală, mai ales la populaţia caucaziană, majoritatea în asociere cu simptomatologia respiratorie. Durerea abdominală izolată este rară $(13,14)$. Câteva studii au evidenţiat importanţa efectuării imagisticii abdominale în cazurile cu afectarea tractului digestiv, pentru a putea surprinde modificări la nivelul bazelor pulmonare, sugestive pentru leziunile date de SARS-CoV-2 (14,15). Acest aspect este confirmat și în cazul prezentat, prin evidenţierea la CT abdominal a pleureziei drepte minime şi a ariilor de hipoventilaţie bazală bilaterală, deși pacientul nu a avut simptomatologie clinică respiratorie semnificativă. Până în prezent, sunt disponibile puţine date despre imagistica abdominală asociată COVID-19. Cele mai consistente informaţii sunt oferite de un studiu în care au fost identificate mai frecvent inflamaţii ale peretelui intestinal și colestază, în concordanţă cu imagistica CT abdominală din cazul nostru (16).

Alterarea neurologică asociată COVID-19 este consecinţa unor mecanisme patogenice complexe, la care contribuie neuroinvazia virală, cu producerea directă a leziunilor neuronale, hipoxia cerebrovasculară, cu ischemia secundară, inflamaţia crescută şi creșterea coagulabilităţii (17).

Manifestările neurologice comune ale COVID-19 indică afectarea sistemului nervos, atât central, cât și periferic, cele mai frecvente acuze fiind amețeala, cefaleea, hiposmia şi disgeuzia (5). Simptomatologia de tip central ar putea fi corelată cu limfopenia, trombocitopenia sau creșterea ureei serice (5). Afectarea neurologică în infecţiile severe poate asocia AVC acute ischemice sau hemoragice, tromboză venoasă cerebrală, encefalopatie, agitaţie psihomotorie sau delir $(5,6,9)$. Riscul de AVC la pacienţii cu COVID-19 a fost estimat la 4,9\%, considerând rezultatele raportate de un studiu din China, în care 13 dintre cei 221 de pacienţi spitalizaţi au dezvoltat AVC, majoritatea de tip ischemic (18).

Majoritatea studiilor indică apariţia evenimentelor cerebrovasculare ischemice mai târziu în cursul bolii $(19,20)$. Totuşi, afectarea neurologică poate să apară şi mai precoce, prin AVC la debut, fără manifestări respiratorii iniţiale, la pacienţi care dezvoltă ulterior în cursul internării insuficienţă respiratorie și leziuni pulmonare caracteristice, așa cum demonstrează unele raportări de cazuri (5). O serie de publicaţii recente indică apariţia accidentelor vasculare cerebrale ischemice de vas mare la pacienţi mai tineri, fără comorbidităţi cardiovasculare, sugerând influenţa potenţială a infecţiei cu SARS-CoV-2 (19,21).

Infecţia COVID-19 nu constituie o contraindicaţie pentru tromboliză la pacienţii eligibili cu AVC ischemic, dar impune precauţii suplimentare de evaluare a raportului beneficiu-risc și respectarea cu strictețe a măsurilor de prevenţie pentru personal, în unităţi dedicate îngrijirii acestor pacienţi (22).

Cauza cea mai probabilă a evenimentului cerebrovascular acut a în acest caz fost considerată fibrilaţia atrială, posibil potenţată de hipercoagulabilitatea asociată infecţiei COVID-19. Decizia trombolizei a fost determinată de considerente etice în beneficiul pacientului, punând în balanţă probabilitatea scăzută pentru infecţia COVID-19 şi şansa celui mai bun prognostic după acest tratament.

\section{CONCLUZII}

Pacienţii cu infecţie COVID-19, mai ales vârstnici şi cu comorbidităţi, au un risc crescut pentru accidente vasculare cerebrale. În context epidemic, suspiciunea infecţiei COVID-19 la pacienţii cu accidente vasculare acute trebuie sa fie maximă, având în vedere posibilitatea evoluţiei atipice, cu absenţa manifestărilor respiratorii. Evaluarea CT abdomino-pelvină poate contribui la identificarea mai frecventă a localizărilor digestive din cursul infecţiei cu SARS-CoV-2. 


\section{BIBLIOGRAFIE}

1. Cevik M, Bamford C, Ho A. COVID-19 pandemic - A focused review for clinicians. Clin Microbiol Infect. 2020.

2. Mao L, Jin H, Wang M et al. Neurologic Manifestations of Hospitalized Patients with Coronavirus Disease 2019 in Wuhan, China. JAMA Neurol. 2020:1-8.

3. Zhou F, Yu T, Du R, et al. Clinical course and risk factors for mortality of adult inpatients with COVID-19 in Wuhan, China: A retrospective cohort study. Lancet. 2020.

4. Ruan $Q$, Yang K, Wang W, Jiang L, Song J. Clinical predictors of mortality due to COVID-19 based on an analysis of data of 150 patients from Wuhan, China. Intensive Care Med. 2020.

5. Mehta P, McAuley DF, Brown M, Sanchez E, Tattersall RS, Manson JJ. COVID-19: Consider cytokine storm syndromes and immunosuppression. Lancet. 2020;395(10229):1033-1034.

6. Cots JM, Alós Jl, Bárcena M, Boleda X, Cañada JL, Gómez N, Mendoza A, Vilaseca I, Llor C. Recommendations for Management of Acute Pharyngitis in Adults. Acta Otorrinolaringologica (English Edition). 2015;66(3):159-70.

7. Chen G, Wu D, Guo W et al. Clinical and immunologic features in severe and moderate Coronavirus Disease 2019. J Clin Invest. 2020.

8. Ahmad I, Rathore FA. Neurological Manifestations and Complications of COVID-19: A Literature Review. J Clin Neurosci. 2020.

9. Helms J, Kremer S, Merdji H et al. Neurologic Features in Severe SARS-CoV-2 Infection. N Engl J Med. 2020:1-2.

10. Cheung KS, Hung IF, Chan PP, et al. Gastrointestinal Manifestations of SARS-CoV-2 Infection and Virus Load in Fecal Samples from the Hong Kong Cohort and Systematic Review and Meta-analysis [published online ahead of print, $2020 \mathrm{Apr} 3$ ]. Gastroenterology. 2020;S0016-5085(20)30448-0.

11. Monitorul Oficial Partea I, nr. 34bis/11.I.2019. Anexa la Ordinul ministrului sănătăţii nr. 17/2019 privind aprobarea protocolului pentru tratament intervenţional al pacienţilor cu accident vascular cerebral acut, din 07.01.2019 - 3-60. http://www.cnas.ro/castr/media/ postFiles/Monitorul\%20Oficial\%20nr\%2034bis_11.01.2019.pdf.

12. Zhou F, Yu T, Du R et al. Clinical course and risk factors for mortality of adult inpatients with COVID-19 in Wuhan, China: A retrospective cohort study. Lancet. 2020;395(10229):1054-1062.

13. Wong SH, Lui RNS, Sung JJY. COVID-19 and the digestive system. J Gastroenterol Hepatol. 2020.

14. Dane B, Brusca-Augello G, Kim D, Katz DS. Unexpected Findings of Coronavirus. AJR. 2020:215:1-4.

15. Siegel A, Chang PJ, Jarou ZJ, et al. Lung Base Findings of Coronavirus Disease (COVID-19) on Abdominal CT in Patients With Predominant Gastrointestinal Symptoms. Am J Roentgenol. 2020.

16. Bhayana R, Som A, Li MD et al. Abdominal Imaging Findings in COVID-19: Preliminary Observations. Radiology. 2020;201908.

17. Tunç A, Ünlübaş Y, Alemdar M, Akyüz E. Coexistence of COVID-19 and acute ischemic stroke report of four cases. $J$ Clin Neurosci. 2020;S0967-5868(20)31081-X.

18. Li Y, Wang M, Zhou Y et al. Acute cerebrovascular disease following COVID-19: A single center, retrospective, observational study. SSRN Electronic Journal 2020.

19. Oxley TJ, Mocco J, Majidi S et al. Large-Vessel Stroke as a Presenting Feature of COVID-19 in the Young. N Engl J Med. 2020.

20. Valderrama EV, Humbert K, Lord A, Frontera J, Yaghi S. Severe Acute Respiratory Syndrome Coronavirus 2 Infection and Ischemic Stroke. Stroke. 2020.

21. Qureshi Al, Abd-Allah F, Al-Senani F, Jani V et al. Management of acute ischemic stroke in patients with COVID-19 infection: Report of an international panel. International Journal of Stroke 2020.

22. Baracchini $C$, Pieroni $A$, Viaro $F$ et al. Acute stroke management pathway during Coronavirus-19 pandemic. Neurol Sci. 2020; 41:1003-1005. 